\title{
Pengaruh Jenis dan Konsentrasi Gelling Agent pada Karakteristik Formula Gel Antiseptik Ekstrak Etanol 70\% Kulit Buah Pisang Ambon
}

\author{
Dyera Forestryana ${ }^{a, 1^{*}}$, Muhammad Surur Fahmia,2, Aristha Novyra Putria,3 \\ a Sekolah Tinggi Ilmu Kesehatan Borneo Lestari Banjarbaru, Banjarbaru, Kalimantan Selatan, Indonesia, 707I4 \\ dyeraforestryana21@gmail.com \\ korespondensi penulis
}

\begin{tabular}{ll}
\hline INFO ARTIKEL & ABSTRAK \\
\hline Diterima : & Ekstrak etanol 70\% kulit buah pisang Ambon mengandung alkaloid, \\
3I-05-2020 & $\begin{array}{l}\text { flavonoid, dan tanin yang memiliki aktivitas sebagai antibakteri. Tujuan } \\
\text { Revisi : }\end{array}$ \\
24-06-2020 & gelling agent terhadap karakteristik fisik gel ekstrak etanol 70\% kulit buah \\
Disetujui : & pisang Ambon. Sediaan gel antiseptik ekstrak etanol kulit buah pisang \\
26-06-2020 & dibuat dalam 4 formula dengan variasi basis dan konsentrasi basis gel yaitu \\
& FI (Na-CMC 5\%), FII (Na-CMC 3\%), FIII (Tragakan 5\%), dan FIV \\
\hline Kata kunci: & (Tragakan 2,5\%). Evaluasi terhadap sediaan dilakukan untuk mengetahui \\
Kulit pisang Ambon; & formula optimum yang memenuhi kriteria persyaratan. Evaluasi yang \\
Antibakteri; & dilakukan meliputi organoleptis homogenitas, daya sebar, daya lekat, pH \\
Gel antiseptic; & dan viskositas. Analisis dilakukan secara statistik menggunakan ANOVA \\
Gelling agent; & dengan tingkat kepercayaan 95\% untuk melihat perbedaan antar \\
Na-CMC. & kelompok formula dan korelasi regresi linier untuk mengetahui pengaruh \\
& jenis dan konsentrasi gelling agent terhadap karakteristik gel antiseptik \\
ekstrak etanol kulit buah pisang Ambon. Formula optimum diperoleh pada & FI dengan basis gel Na-CMC pada konsentrasi 5\% karena memenuhi \\
kriteria syarat gel yang baik.
\end{tabular}

\section{Keywords:}

Ambon banana peel;

Antibacteria;

Antiseptic gel;

Gelling agent;

$\mathrm{Na}-\mathrm{CMC}$.

\section{ABSTRACT}

Ethanol extract of 70\% Ambon banana peel contains alkaloids, flavonoids, and tannins, which has antibacterial activity. The aims of this study to determine the effect of type and concentration of gelling agents on the physical characteristics of antiseptic gel formula Ambon banana peel 70\% ethanolic extract. The antiseptic gel formula of banana peel $70 \%$ ethanolic extract made in 4 formulas with variations in type and concentration gelling agent, namely FI (Na-CMC 5\%), FII (Na-CMC 3\%), FIII (Tragakan 5\%), and FIV (Tragakan 2,5\%). Evaluation of the formulas done to find out the best formula that meets the requirements criteria. The evaluations included organoleptic, homogeneity, spreadability, adhesion, $\mathrm{pH}$, and viscosity. The analysis performed statistically using ANOVA with a confidence level of $95 \%$ to see differences between groups of formulas and linear regression correlation to determine the effect of type and concentration of gelling agent on the characteristics of the antiseptic gel of Ambon banana peel. The optimum formula is obtained on FI based on $\mathrm{Na}-\mathrm{CMC}$ of $5 \%$ because it meets the criteria for gel requirements.

This is an open access article under the CC-BY-SA license.

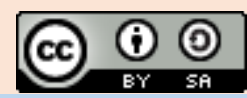

\section{Pendahuluan}

Pisang merupakan tumbuhan yang memiliki banyak manfaat bagi masyarakat. Bagian tumbuhannya dapat dimanfaatkan sebagai bahan pangan maupun sebagai obat tradisional. Buah 
pisang paling banyak diminati oleh masyarakat karena rasanya yang manis. Makanan yang paling digemari oleh masyarakat adalah pisang goreng. Pisang ambon merupakan salah satu jenis pisang yang cocok untuk dijadikan pisang goreng. Namun, dibalik banyaknya masyarakat yang mengkonsumsi buah pisang, ada kulit pisang yang terbuang percuma dan dijadikan sebagai limbah.

Bobot kulit buah pisang mencapai 40\% dari buahnya, sehingga kulit pisang merupakan penghasil limbah dengan volume yang besar. Kulit buah pisang ambon ternyata memiliki kandungan senyawa seperti tanin, flavonoid, saponin dan alkaloid yang memiliki aktivitas sebagai penghambat pertumbuhan bakteri (Normayunita, 2015). Menurut Ighodaro (2012), ekstrak etanol 70\% kulit buah pisang ambon memiliki kosentrasi hambatan minimum sebesar $50 \mathrm{mg} / \mathrm{mL}$ terhadap Staphylococcus auerus.

Pemanfaatan limbah kulit buah pisang sebagai antibakteri dapat dikembangkan pada formulasi sediaan farmasi dalam bentuk sediaan gel antiseptik. Gel merupakan sediaan yang ditujukan untuk penggunaan topikal. Sediaan gel dianggap sesuai untuk penghantaran senyawa pada kulit buah pisang sebagai antiseptik karena memiliki keuntungan mudah diaplikasikan, tidak memberikan rasa lengket di tangan, memberikan kelembaban pada kulit, meninggalkan sensasi rasa dingin pada kulit dan zat aktif dapat terpenetrasi dengan baik karena kandungan gel yang sebagian besar adalah air (Yulia, 20I2).

Pada pembuatannya, diperlukan gelling agent yang merupakan faktor penting dalam pembuatan gel karena dapat mempengaruhi karakteristik sediaan. Gelling agent merupakan suatu polimer yang memiliki karakteristik berbeda, sehingga diperlukan pertimbangan khusus dalam pemilihan gelling agent sebagai base dari sediaan gel. Karakteristik gelling agent yang digunakan harus disesuaikan dengan jenis sediaan karena semakin tinggi konsentrasi gelling agent yang digunakan, semakin tinggi viskositas gel karena struktur gel semakin kuat (Setyaningrum, 2013). Pada formulasi sediaan gel ekstrak kulit pisang Ambon ini digunakan dua gelling agent yaitu $\mathrm{Na}-\mathrm{CMC}$ dan tragakan dengan berbagai konsentrasi penggunaan.

$\mathrm{Na}-\mathrm{CMC}$ merupakan semi sintetis gelling agent sedangkan tragakan merupakan golongan natural gelling agent. Kedua gelling agent ini memiliki sifat yang berbeda pada penggunannya sebagai gelling agent, sehingga tujuan dari penelitian ini adalah untuk melihat pengaruh gelling agent tersebut pada karakteristik fisik sediaan gel antiseptik ekstrak etanol kulit buah pisang ambon.

\section{Metode}

Alat dan Bahan

Alat-alat yang digunakan pada penelitian ini adalah neraca analitik (Pioneer PA2I4C, Ohaus, US), vacum rotary evaporator (IKA RVIO, Germany), seperangkat alat maserasi, $\mathrm{pH}$ meter (Hanna, Indonesia), waterbath (Memmert, WNB I4 Ring, Germany), oven (Memmert, Germany), magnetic stirrer (SSM 79-I, China), viskometer stormer (NDJ-5S, China).

Bahan yang digunakan pada penelitian ini adalah kulit buah pisang ambon, aquades $\left(\mathrm{H}_{2} \mathrm{O}\right)$, etanol 70\%, gliserin, trietanolamin (TEA), metil paraben, propilenglikol, tragakan dan $\mathrm{Na}-\mathrm{CMC}$.

\section{Prosedur}

\section{Ekstraksi maserasi kulit buah pisang ambon}

Ekstraksi dilakukan dengan cara maserasi. Serbuk kulit buah pisang (800 g) di maserasi dengan pelarut etanol 70\%. Sampel tersebut direndam selama 3 kali 24 jam sambil dilakukan pengadukan. Ekstrak cair yang diperoleh tersebut diuapkan menggunakan rotary evaporator dan dilanjutkan dengan waterbath hingga diperoleh ektrak kental kulit buah pisang ambon.

\section{Formulasi sediaan gel antiseptik ekstrak etanol kulit buah pisang}

Formula gel antiseptik ekstrak etanol kulit buah pisang dapat dilihat pada Tabel I.

Tabel I. Formulasi gel ekstrak kulit buah pisang

\begin{tabular}{|c|c|c|c|c|}
\hline Komponen & $\begin{array}{l}\text { FI } \\
(\%)\end{array}$ & $\begin{array}{l}\text { F2 } \\
(\%)\end{array}$ & $\begin{array}{l}\text { F3 } \\
(\%)\end{array}$ & $\begin{array}{c}\mathrm{F} 4 \\
(\%)\end{array}$ \\
\hline Ekstrak etanol & & & & \\
\hline $\begin{array}{l}\text { kulit buah } \\
\text { pisang }\end{array}$ & 5 & 5 & 5 & 5 \\
\hline $\mathrm{Na}-\mathrm{CMC}$ & 5 & 3 & - & - \\
\hline Tragakan & - & . & 5 & 2,5 \\
\hline TEA & 2 & 2 & 2 & 2 \\
\hline Gliserin & I0 & 10 & 10 & I0 \\
\hline Propilenglikol & 5 & 5 & 5 & 5 \\
\hline Metil paraben & 0,2 & 0,2 & 0,2 & 0,2 \\
\hline Aquadest ad & 100 & 100 & 100 & 100 \\
\hline
\end{tabular}

Pembuatan gel dilakukan dengan mengembangkan gelling agent ( $\mathrm{Na}-\mathrm{CMC}$ dan tragakan) dalam $20 \mathrm{~mL}$ air pada suhu $70^{\circ} \mathrm{C}$ dengan dilakukan pengadukan secara konstan hingga terbentuk massa yang homogen. 
Kemudian ditambahkan metil paraben yang telah dilarutkan dengan sedikit air, dan selanjutnya ditambahkan gliserin, propilenglikol dan TEA sambil dilakukan pengadukan hingga homogen. Kemudian ditambahkan ekstrak kulit buah pisang dan sisa air, aduk hingga homogen dan terbentuk massa gel (Sugihartini, 20I5).

\section{Evaluasi fisik gel antiseptik ekstrak etanol kulit buah pisang Karakteristik organoleptik}

Uji organoleptis merupakan jenis evaluasi yang mengamati penampilan luar dari sediaan gel. Pengamatan dilakukan terhadap bentuk, warna dan bau dari sediaan yang dibuat (Anief, I997).

\section{Homogenitas}

Dilakukan dengan mengoleskan gel pada sekeping kaca dan diamati adaanya partikel pada sediaan gel (Astuti, 2017).

pH

Dilakukan dengan menggunakan $\mathrm{pH}$ meter.

\section{Daya sebar}

Sebanyak 0,5 gram gel diletakkan pada kaca datar, kaca lainnya diletakkan di atasnya dan dibiarkan selama I menit. Setelah itu, ditambahkan I50 gram beban didiamkan I menit dan diukur diameter konstan. Daya sebar gel yang baik antara 5-7 cm (Sugihartini, 2015).

\section{Daya lekat}

Sebanyak 0,25 gram gel diletakkan diantara 2 kaca objek pada alat uji daya lekat, kemudian diletakkan beban I kg selama 5 menit, beban dilepas dan pasang beban 80 gram pada alat uji, kemudian dilepaskan beban tersebut, waktu yang diperlukan sampai kaca objek tersebut terlepas dicata sebagai waktu lekat gel. Syarat untuk daya lekat pada sediaan topikal pada penelitian sebelumnya disebutkan adalah tidak kurang dari 4 detik (Sugihartini, 2015).

\section{Viskositas}

Sediaan gel diletakkan pada bagian bawah alat uji pada viskometer stormer, kemudian celupkan spindle hingga tenggelam pada sediaan. Atur kecepatan yang digunakan dan viskometer stormer dijalankan, kemudian viskositas dari gel terbaca (Septiani, 2012). Nilai viskositas gel yang baik berada pada rentang 2000-4000 cPs, karena dengan kekentalan tersebut gel mampu menyebar dengan baik saat diaplikasikan (Purwati, 2016).

\section{Penentuan formula optimum}

Penentuan formula optimum berdasarkan pada formula yang memiliki karakteristik fisik sesuai dengan karakteristik yang dipersyaratkan.
Parameter karakteristik yang digunakan adalah daya lekat, daya sebar dan viskositas.

\section{Analisis statistik}

Data yang diperoleh pada pengujian evaluasi kemudian dianalisa menggunakan statistik pada software SPSS V.I8.0. Uji statistik yang dilakukan adalah uji normalitas menggunakan Kolmogorov-Smirnov kemudian dilanjutkan dengan menggunakan analisis variansi satu arah (ANOVA) dengan taraf kepercayaan 95\% untuk melihat adanya perbedaan antar kelompok formula gel. Untuk melihat pengaruh jenis dan konsentrasi gelling agent terhadap daya sebar, daya lekat dan viskositas dianalisis menggunakan uji korelasi dan regresi.

\section{Hasil dan pembahasan}

Ekstrak etanol kulit buah pisang yang diperoleh dari proses ekstraksi maserasi adalah sebesar 125 g dengan rendemen sebesar 15,62\%. Hasil ekstrak tersebut kemudian diformulasikan ke dalam bentuk sediaan gel antiseptik. Tujuan penggunaann gel antiseptik tersebut adalah agar memudahkan dalam pemakaiannya sebagai pembersih tangan. Kebanyakan gel antiseptik yang beredar di masyarakat mengandung bahan kimia yang tentunya kurang aman dalam penggunannya. Gel antiseptik ekstrak etanol kulit buah pisang ini diharapkan dapat memberikan jaminan keamanan dalam hal penggunaan.

Pembuatan gel antiseptik menggunakan gelling agent sebagai bahan pembentuk gel. Gelling agent yang digunakan yaitu Na-CMC dan tragakan. Na-CMC merupakan gelling agent semi sintetis sedangkan tragakan merupakan gelling agent alami. Gelling agent mempengaruhi karakterisitik fisik dari sediaan gel yang dihasilkan. Uji evaluasi terhadap sifat fisik pada sediaan topikal bertujuan untuk menjamin bahwa sediaan gel memiliki mutu sediaan yang baik sehingga dapat tercapainya efek farmakologis sesuai yang diharapkan Hasil evaluasi dapat dilihat pada Tabel 2.

Berdasarkan hasil evaluasi fisik sediaan gel ekstrak etanol kulit buah pisang secara organoleptis, diperoleh sedian gel yang berwarna cokelat tua, memiliki bau seperti aroma pisang dan memiliki tekstur kental seperti gel. Menurut Lachman et al., (1994), sediaan gel pada umumnya berwarna bening atau jernih sedangkan gel antiseptik kulit buah pisang berwarna coklat tua, hal ini disebabkan oleh ekstrak kulit buah pisang yang berwarna cokelat. Tampilan sediaan gel antiseptik ekstrak kulit buah pisang dapat dilihat pada Gambar I. 


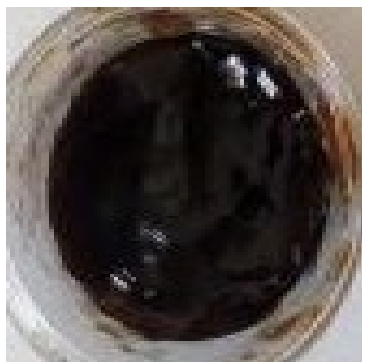

Gambar I. Sediaan gel antiseptik ekstrak etanol kulit buah pisang

Pengujian homogenitas bertujuan untuk mengetahui ada atau tidaknya partikel pada pada sediaan gel. Hal ini penting untuk diketahui, karena ketidakhomogoenan suatu komponen di dalam suatu sediaan akan mempengaruhi efikasi yang dihasilkan (Numberi, 2020). Homogenitas suatu sediaan ditandai dengan adanya partikel kasar yang ada pada sediaan gel karena tidak terdispersi dengan baik. Berdasarkan uji homogenitas, menunjukkan bahwa pada keempat sediaan gel antiseptik tidak ditemukan adanya partikel kasar sehingga dapat dinyatakan bahwa sediaan gel antiseptik ekstrak etanol kulit buah pisang adalah homogen.

Hasil pengujian $\mathrm{pH}$ untuk keempat formula gel secara berturut-turut adalah 6,73 $\pm 0,208$;

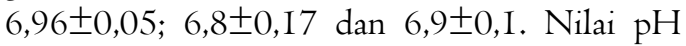
tersebut berada dalam kisaran nilai $\mathrm{pH}$ yang terdapat pada SNI 16-4399-1996 sebagai syarat mutu sediaan kulit $(4,5-8,0)$ dan $\mathrm{pH}$ yang sesuai dengan pH kulit yaitu antara 4,5-7,5 (Faradiba, 2013). Sediaan topikal sedemikian mungkin harus memiliki $\mathrm{pH}$ yang sama dengan kulit agar bisa berdifusi kedalam kulit (Martin, I993). Jika $\mathrm{pH}$ sediaan terlalu basa, maka dapat mengakibatkan kulit kering sedangkan jika $\mathrm{pH}$ terlalu asam, maka dapat memicu terjadinya iritasi kulit (Mappa, 2013; Swastika, 2013).

Daya sebar merupakan kemampuan suatu sediaan untuk menyebar pada kulit setelah dioleskan. Daya sebar berkaitan dengan viskositas suatu sediaan, Sediaan yang memiliki viskositas lebih besar maka akan semakin sulit untuk dioleskan pada kulit, sehingga memberikan daya sebar yang kecil. Semakin besar daya sebar suatu sediaan maka akan semakin mudah untuk obat berdifusi ke dalalam kulit. Hal tersebut dikarenakan, dengan semakin luasnya area penyebaran, maka akan menyediakan luas permukaan membran yang besar untuk obat berdifusi ke dalam kulit, sehingga jumlah zat yang terpenetrasi akan lebih banyak dan tercapai efikasi maksimum (Ali, 2015). Data yang diperoleh untuk pengujian ini ada 2 yaitu diameter sebar sediaan dan daya sebar suatu sediaan. Diameter sebar merupakan luas area penyebaran sedangkan daya sebar adalah daya yang diberikan untuk mengoleskan suatu sediaan gel tersebut. Berdasarkan pengujian diameter sebar, diperoleh diameter penyebaran untuk keempat formula adalah berada pada rentang $4,67 \mathrm{~cm}-5,233 \mathrm{~cm}$. Menurut Sugihartini (2015), diameter penyebaran sediaan topical yang baik adalah berkisar $5-7 \mathrm{~cm}$. Hal ini membuktikan bahwa diameter penyebaran untuk formula gel antiseptik memenuhi persyaratan diameter sebar gel. Pada penggunaannya sebagai gel antiseptik, diharapkan sediaan gel yang mudah untuk dioleskan dan memberikan penyebaran yang baik.

Peningkatan konsentrasi Na-CMC dapat mempengaruhi pembentukan matriks gel. Matrik gel $\mathrm{Na}-\mathrm{CMC}$ terbentuk dari perpanjangan rantai polimer, semakin banyak Na-CMC yang digunakan maka matrik gel yang terbentuk akan semakin rapat, selain itu dengan adanya air, $\mathrm{Na}^{+}$ akan lepas dan diganti dengan ion $\mathrm{H}^{+}$ membentuk HCMC yang akan meningkatkan viskositas dengan terbentuknya cross linking. Ikatan hydrogen ini akan menurunkan kelarutan $\mathrm{Na}-\mathrm{CMC}$ dalam air dan menghasilkan formasi hydrogel yang elastis. Semakin banyak $\mathrm{Na}-\mathrm{CMC}$ di dalam air maka akan banyak ikatan hidrogen yang terbentuk dan membuat gel akan semakin rigid (Yuliani, 2012). Pada tragakan, mekanisme pembentukan gel terjadi karena adanya pembentukan jaringan tiga dimensi pada polimernya. Air akan terjerap di dalam dimensi tersebut dan gel akan terbentuk. Semakin banyak air yang digunakan maka akan semakin banyak air yang terjerap sehingga mengakibatkan peningkatan viskositas (Herawati, 2018). Jika konsentrasi tragakan yang digunakan tinggi maka akan meningkatkan viskositasnya. Daya sebar yang kecil disebabkan karena adanya peningkatan konsentrasi gelling agent. Salah satu factor yang mempengaruhi daya sebar gel adalah jumlah dan kekuatan matriks gel. Semakin banyak dan kuat matriks gel maka daya sebar akan berkurang. Dalam sistem gel yang bertanggung jawab terhadap pembentukan matriks gel adalah gelling agent. Dengan demikian konsentrasi gelling agent menambah dan memperkuat matriks gel (Rohmani, 2019). 
Tabel 2. Hasil evaluasi uji karakteristik gel antiseptik ekstrak etanol kulit bauah pisang

\begin{tabular}{|c|c|c|c|c|}
\hline $\begin{array}{c}\text { Evaluasi } \\
U_{j i}\end{array}$ & FI & $\mathrm{F} 2$ & F3 & F4 \\
\hline $\begin{array}{l}\text { Organole } \\
\text { ptis }\end{array}$ & & & & \\
\hline Bentuk & $\begin{array}{c}\text { Semisol } \\
\text { id }\end{array}$ & $\begin{array}{c}\text { Semiso } \\
\text { lid }\end{array}$ & $\begin{array}{c}\text { Semisol } \\
\text { id }\end{array}$ & $\begin{array}{c}\text { Semisoli } \\
\mathrm{d}\end{array}$ \\
\hline Bau & $\begin{array}{c}\text { Khas } \\
\text { kulit } \\
\text { pisang } \\
\end{array}$ & $\begin{array}{c}\text { Khas } \\
\text { kulit } \\
\text { pisang }\end{array}$ & $\begin{array}{c}\text { Khas } \\
\text { kulit } \\
\text { pisang }\end{array}$ & $\begin{array}{l}\text { Khas } \\
\text { kulit } \\
\text { pisang } \\
\end{array}$ \\
\hline Warna & $\begin{array}{c}\text { Coklat } \\
\text { tua }\end{array}$ & $\begin{array}{c}\text { Coklat } \\
\text { tua }\end{array}$ & $\begin{array}{c}\text { Coklat } \\
\text { tua }\end{array}$ & $\begin{array}{c}\text { Coklat } \\
\text { tua }\end{array}$ \\
\hline $\begin{array}{l}\text { Homoge } \\
\text { nitas }\end{array}$ & $\begin{array}{c}\text { Homog } \\
\text { en }\end{array}$ & $\begin{array}{c}\text { Homo } \\
\text { gen }\end{array}$ & $\begin{array}{c}\text { Homog } \\
\text { en }\end{array}$ & $\begin{array}{c}\text { Homog } \\
\text { en }\end{array}$ \\
\hline $\mathrm{pH}$ & $\begin{array}{c}6,73 \pm \\
0,208\end{array}$ & $\begin{array}{c}6,96 \pm \\
0,05\end{array}$ & $\begin{array}{l}6,8 \pm \\
0,17\end{array}$ & $\begin{array}{l}6,9 \pm \\
0,10\end{array}$ \\
\hline $\begin{array}{l}\text { Daya } \\
\text { Sebar }\end{array}$ & $\begin{array}{c}\text { I I,67 } \\
\pm 0,14 \\
\text { (g.cm/s } \\
\text { ec) }\end{array}$ & $\begin{array}{c}13,08 \\
\pm \mathrm{I}, 0 \mathrm{I} \\
\text { (g.cm/ } \\
\mathrm{sec})\end{array}$ & $\begin{array}{c}\text { II,62 } \\
\pm 0,52 \\
\text { (g.cm/ } \\
\text { sec) } \\
\end{array}$ & $\begin{array}{c}\mathrm{I} 2,67 \pm \\
0, \mathrm{I} 4 \\
(\mathrm{~g} \cdot \mathrm{cm} / \mathrm{s} \\
\mathrm{ec} \text { ) }\end{array}$ \\
\hline $\begin{array}{l}\text { Daya } \\
\text { lekat }\end{array}$ & $\begin{array}{l}69 \pm \\
0,2 I \\
\text { detik }\end{array}$ & $\begin{array}{l}45 \pm \\
0,04 \\
\text { detik }\end{array}$ & $\begin{array}{l}90 \pm \\
0,15 \\
\text { detik }\end{array}$ & $\begin{array}{l}59 \pm \\
1,34 \\
\text { detik } \\
\end{array}$ \\
\hline $\begin{array}{l}\text { Viskosit } \\
\text { as }\end{array}$ & $\begin{array}{c}3980 \pm \\
\mathrm{II}, 46 \\
(\mathrm{cPs})\end{array}$ & $\begin{array}{c}2480 \\
\pm \\
24,21 \\
(\mathrm{cPs}) \\
\end{array}$ & $\begin{array}{c}9340 \\
\pm \\
\mathrm{I} 4,49 \\
(\mathrm{cPs})\end{array}$ & $\begin{array}{c}4860 \pm \\
25,67 \\
(\mathrm{cPs})\end{array}$ \\
\hline
\end{tabular}

Keterangan:

FI : Geliing agent $\mathrm{Na}-\mathrm{CMC}(5 \%)$

$\mathrm{F} 2$ : Geliing agent $\mathrm{Na}-\mathrm{CMC}(3 \%)$

F3: Geliing agent Tragakan (5\%)

F4 : Geliing agent Tragakan (2,5\%)

$\mathrm{Na}-\mathrm{CMC}$ sebagai gelling agent memiliki berat molekul berkisar 90000-700000 sedangkan tragakan memiliki berat molekul berkisar 250000-1000000. Semakin besar berat molekul maka akan semakin kental sediaan tersebut dan akan mempengaruhi daya sebar sediaan. Hal ini dapat dilihat pada hubungan antara konsentrasi gelling agent dan daya sebar pada Gambar 2. Hasil analisis korelasi regresi pada gelling agent $\mathrm{Na}-\mathrm{CMC}$ didapat persamaan yaitu $y=-0,705 x+15,195$ terhadap daya sebar gel, persamaan ini menunjukkan bahwa konsentrasi $\mathrm{Na}-\mathrm{CMC}$ berpengaruh terhadap daya sebar gel dengan nilai slope negatif, yaitu - 0,705, yang artinya semakin tinggi konsentrasi $\mathrm{Na}$ CMC maka daya sebar sediaaan gel semakin kecil. Nilai intersep merupakan nilai konsisten varibel daya sebar adalah I5,195. Pengaruh penambahan $\mathrm{Na}-\mathrm{CMC}$ terhadap daya sebar gel ekstrak etanol kulit buah pisang sebesar 100\% yang ditunjukkan dengan nilai $\mathrm{R}^{2}=\mathrm{I}$. Pada gelling agent tragakan diperoleh persamaan $y=-0,42 \mathrm{x}$ $+13,72$, dimana bertambahnya $1 \%$ konsentrasi gelling agent akan menurunkan daya sebar gel seperti pada gelling agent $\mathrm{Na}-\mathrm{CMC}$. Sedangkan berdasarkan analisis statistik, data pada pengujian daya sebar terdistribusi normal dengan nilai $p$ value adalah 0,217 ( $p$-value $>0,05)$ sedangkan pada pengujian ANOVA deperoleh nilai signifikansi yaitu 0,084 ( $p$-value $<0,05)$, hal ini menunjukkan bahwa tidak terdapat perbedaan bermakna pada penggunaan gelling agent $(\mathrm{Na}$ CMC dan tragakan) dan konsentrasi gelling agent yang digunakan.

Pada pengujian daya lekat diperoleh daya lekat yang baik pada keempat sediaan gel antiseptik dengan kisaran waktu lekat yaitu 4590 detik. Daya lekat yang baik untuk sediaan topikal adalah lebih dari 4 detik, ini menunjukkan bahwa sediaan gel antiseptik ekstrak etanol kulit buah pisang memiliki waktu lekat yang cukup lama. Pada FI dan F2 dengan gelling agent yang digunakan adalah $\mathrm{Na}-\mathrm{CMC}$ dengan kosentrasi $5 \%$ dan 2,5\% diperoleh waktu lekat secara berturut-turut yaitu 69 detik dan 45 detik. Sedangkan pada F3 dan F4 dengan gelling agent tragakan, diperoleh waktu lekat secara berturut-turut yaitu 90 detik dengan konsentrasi $5 \%$ dan 59 detik dengan konsentrasi tragakan 2,5\%. Hasil ini menunjukkan jika penggunaan gelling agent dan konsentrasi penggunaan gelling agent berpengaruh pada daya lekat yang dihasilkan. Semakin besar konsentrasi yang digunakan maka akan meningkatkan waktu lekat sediaan gel. Daya lekat yang semakin lama memungkinkan obat untuk melepaskan zat aktifnya lebih banyak ke dalam kulit, karena kontak antara gel dengan kulit akan lebih lama sehingga terapi yang diinginkan akan maksimum (Dewi, 2016). Hasil analisis korelasi regresi pada gelling agent $\mathrm{Na}$ CMC dan tragakan pada Gambar 2 menunjukan bahwa adanya nilai slope ang positif, yang artinya setiap kenaikan I\% konsentrasi akan menaikkan daya lekat sediaan gel ekstrak etanol kulit buah pisang. Sehingga pengaruh konsentrasi terhadap daya kekat adalah sebesar $100 \%$ jika dilihat pada nilai $R^{2}=I$. Berdasarkan uji normalitas dan homogenitas pada pengujian daya lekat, menunjukkan data pada pengujian ini terdistribusi normal dengan $p$-value 0,848 ( $p$-value $>0,05$ ) Selanjutnya pada analisis menggunakan ANOVA diperoleh nilai signifikansi yaitu 0,000 ( $p$-value $<0,05)$ sehingga ada perbedaan bermakna pada keempat formula gel tersebut karena pengaruh gelling agent dan konsentrasi gelling agent. 

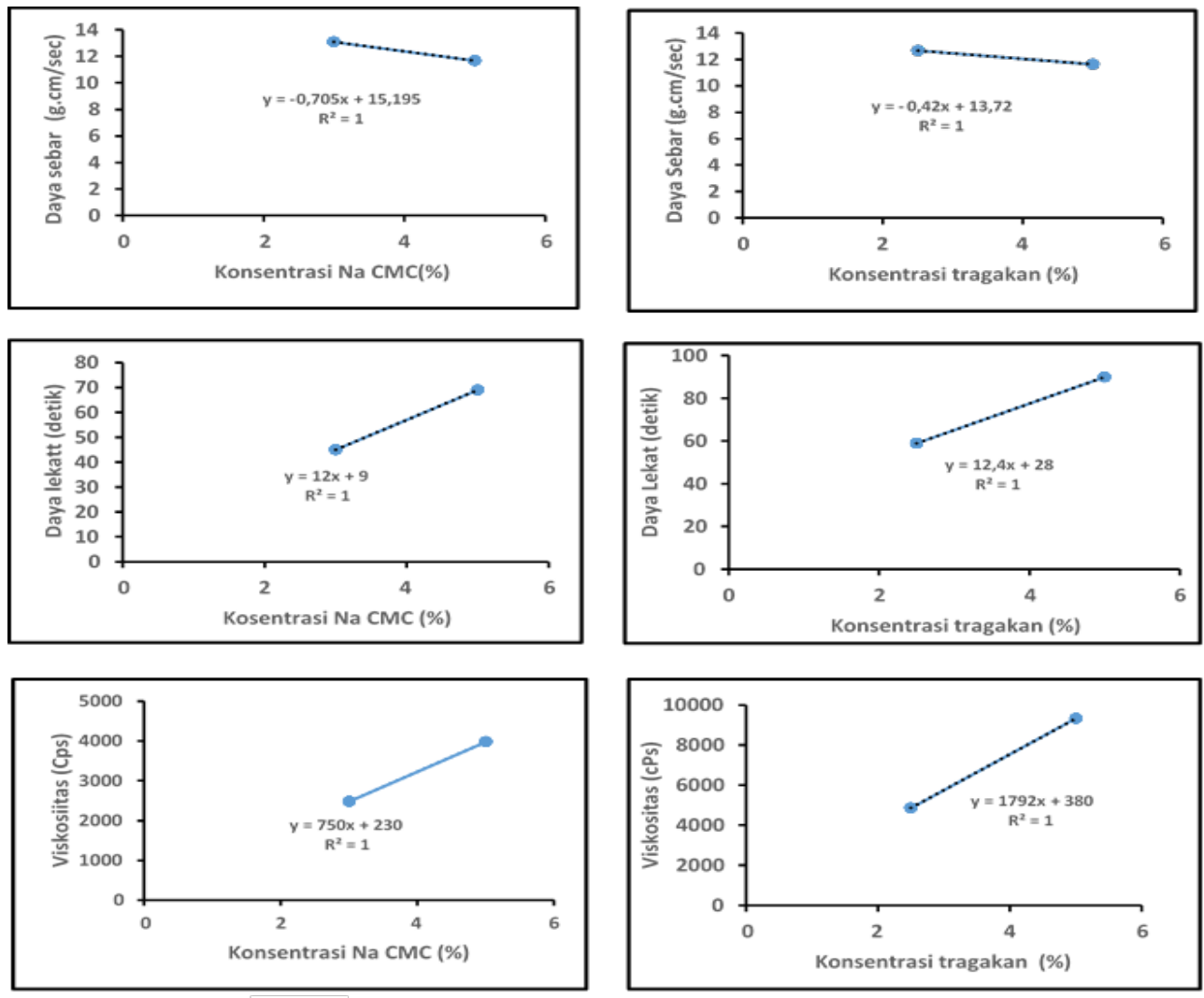

A

B

Gambar 2. Grafik korelasi regresi konsentrasi gelling agent $\mathrm{Na} C M C$ (A) dan tragakan (B) terhadap daya sebar, daya lekat dan viskositas.

Viskositas menggambarkan kekentalan suatu sediaan, yang berhubungan dengan daya sebar dan daya lekat. Dalam formulasi sediaan gel antiseptik, viskositas yang diinginkan adalah tidak terlalu viscose karena jika terlalu kental maka akan sulit untuk dioleskan sehingga akan membuat rasa tidak enak pada saat digunakan. Viskositas yang baik adalah pada rentang 2000-4000 cPs, karena dengan kekentalan tersebut gel mampu menyebar dengan baik saat diaplikasikan (Purwati, 2016).

Pada Gambar 2 dapat dilihat hubungan korelasi konsentrasi geliing agent terhadap viskositas. Slope yang diperoleh untuk masingmasing gelling agent memiliki nilai positif, dengan $\mathrm{R}^{2}=\mathrm{I}$. Sehingga pengaruh konsentrasi adalah 100\% terhadap viskositas sediaan gel. Dimana semakin besar konsentrasi gelling agent maka viskositas sediaan juga akan meningkat. Berdasarkan uji normalitas diperoleh p-value $>$ 0,05 yaitu 0,308 , ini mengindikasikan bahwa data terdistribusi normal, sehingga dapat dilanjutkan pada pengujian ANOVA. Pada analisis menggunakan ANOVA diperoleh nilai signifikansi 0,000 ( $p$-value $<0,05$ ), pada keempat formula tersebut terdapat perbedaan bermakna karena pengaruh penggunaan gelling agent dan konsentrasi penggunannya.
Pada pengujian viskositas, FI dan F2 dengan $\mathrm{Na}-\mathrm{CMC}$ sebagai gelling agent memiliki viskositas berturut-turut yaitu diperoleh viskositas 3980 cps dan 2480 cps sedangkan pada F3 dan F4 secara berturut-turut adalah 9340 cps dan 4860 cps. Berdasarkan data ini maka dapat disimpulkan bahwa $\mathrm{Na}-\mathrm{CMC}$ sebagai gelling agent memiliki viskositas yang sesuai dengan persyaratan karena $\mathrm{Na}$-CMC memiliki berat molekul yang lebih kecil dibandingkan dengan tragakan.

\section{Simpulan dan Saran}

Formula terbaik diperoleh pada F2 dengan $\mathrm{Na}-\mathrm{CMC}$ sebagai gelling agent pada konsentrasi $5 \%$, karena memiliki karakteristik yang sesuai dengan persyratan gel antiseptik. Penggunaan jenis gelling agent dan konsentrasi gelling agent yang digunakan berpengaruh pada karakteristik fisik sediaan gel seperti daya sebar, daya lekat dan viskositas.

\section{Daftar pustaka}

Ali, N., W., (2015), Pengaruh perbedaan tipe basis terhadap sifat fisik sediaan salep ekstrak etanol daun tapak kuda (Ipomoea Pes-caprae (L) Sweet), Pharmacon, 4(3), IIO-II6. 
Anief, M., (I997), Ilmu meracik obat, Yogyakarta.

Astuti, D., P., Husni, P., \& Hartono, K., (2017), Formulasi dan uji stabilitas fisik sediaan gel antiseptik tangan minyak atsiri bunga lavender (lavandula angustifolia miller), Farmaka, I5(I), I76-I84.

Dewi, C., C., \& Saptarini, N., M., (2016), Hidroksi propil metil selulosa dan karbomer serta sifat fisikokimianya sebagai gelling agent, Farmaka, I4(3), I-IO.

Faradiba, F., A., \& Ruhama, M., (2013), Formulasi krim wajah dari sari buah jeruk lemon (vitis vinifera 1.) dengan variasi konsentrasi elmugator, Majalah Farmasi dan Farmakologi, I7(I), I720.

Herawati, H., (2018), Potensi hidrokoloid sebagai bahan tambahan pada produk pangan dan nonpangan bermutu, Jurnal Litbang Penelitian, 37(I), I7-25.

Ighodaro, O., M., (2012), Evaluation study on nigerian species of musa paradisiaca peels, Researcher, 4(8), 17-20.

Lachman, L., Lieberman, H.A., \& Kanig, J.L., (I994), Teori dan praktek farmasi industri, diterjemahkan oleh Siti Suyatmi dan Iis Aisyiah, edisi III, jilid 2, Universitas Indonesia Press, Jakarta.

Mappa, T., Edi, J, H \& Kojong, M,. (2013), Formulasi gel ekstrak daun sasaladahan (pperomia pellucida 1.) dan uji efektivitasnya terhadap luka bakar pada kelinci, Jurnal Ilmiah Farmasi, 2(20), 49-56.

Martin, A., Swarbrick, J., \& Cammarata, A., (I993), Farmasi Fisika 2 Edisi III terjemahan Yoshita.

Normayunita, S., Anam, S., \& Khumaidi, A., (2015), Aktivitas antibakteri fraksi ekstrak kulit buah mentah pisang ambon (musa paradisiaca var. sapientum) terhadap staphylococcus aureus, Natural Science: Journal of Science and Technology, 4(3), 300309.

Numberi, A., M., Rani, D., \& Elsye, G., (2020), Uji stabilitas fisik sediaan masker gel dari ekstrak alga merah (Poryphyra sp), Majalah farmasetika, 5(I), I-I7.

Purwati \& Verryanti, (2016), Aktivitas antioksidan dan evuluasi fisik sediaan masker gel peel off dari ekstrak kulit terung ungu (salonum melongena 1.),
Indonesia Natural Research Pharmaceutikal Journal, I(2), I0-2I.

Rohmani, S., Muhammad, A., A., K., (2019), Uji stabilitas dan aktivitas gel handsanitizer ekstrak daun kemangi, Journal of Pharmaceutical Science and Clinical Research, 0I, 16-28.

Septiani, S., (2012), Formulasi sediaan masker gel antioksidan dari ekstrak etanol biji melinjo (Gnetun gnemon Linn.), Students e-Journal, I(I), 39.

Setyaningrum, N., L., (2013). Pengaruh variasi kadar basis hpme dalam sediaan gel ekstrak etanolik bunga kembang sepatu (Hibiscus rosa sinensis L.) terhadap sifat fisik dan daya antibakteri pada Staphylococcus aureus, Doctoral dissertation, Universitas Muhammadiyah Surakarta.

Sugihartini, N., \& Lena, M., (2015), Formula gel ekstrak etanol kulit buah manggis (garcinia mangostana 1.) dengan variasi gelling agent sebagai sediaan luka bakar, Pharmaciana, 5(I), 43-52.

Swastika, A., Mufrod \& Purwanto, (2013), Aktivitas antioksidan krim ekstrak sari tomat (Solanum lycopersicum L.), Trad Med Journal, I8(3): I32-I40.

Yulia, A., Esti, H, Tutiek P., (2012), Karakteristik sediaan dan pelepasan natrium diklofenak dalam sisten niosom dengan basis gel carbomer 940, PharmaScientia, I (I):2

Yuliani, S., H., (2012), Formulasi sediaan hidrogel penyembuh luka ekstrak etanol daun Binahong (Anredera cordifolia (Ten) Steenis), (Doctoral dissertation, Fakultas Farmasi UGM, Yogyakarta. 